\title{
KARAKTERISTIK PRODUK ULI KHAS SUKU BADUI DENGAN PENAMBAHAN DAGING IKAN BANDENG
}

\author{
Fitria Riany Eris ${ }^{1,2 *}$, Aris Munandar ${ }^{2,3}$, Taufik Hidayat ${ }^{4}{ }^{4}$ Kartina $\mathrm{AM}^{5}$, \\ Meutia $^{6}$, Dian Anggraeni ${ }^{6}$, \\ ${ }^{1}$ Program Studi Teknologi Pangan, Fakultas Pertanian, Universitas Sultan Ageng Tirtayasa \\ ${ }^{2}$ Indonesian Center of Excellent for Food Security, Universitas Sultan Ageng Tirtayasa Jalan. Raya Jkt Km 4 \\ Pakupatan, Panancangan, Kec. Cipocok Jaya, Kota Serang, Banten 42124, \\ ${ }^{3}$ Program Studi Ilmu Perikanan, Fakultas Pertanian, Universitas Sultan Ageng Tirtayasa Jalan. Raya Jkt \\ Km 4 Pakupatan, Panancangan, Kec. Cipocok Jaya, Kota Serang, Banten 42124, \\ ${ }^{4}$ Pusat Teknologi Agroindustri, Kedeputian Teknologi Agroindustri dan Bioteknologi, Badan Pengkajian \\ dan Penerapan Teknologi Puspiptel Serpong, Banten \\ ${ }^{5} J u r u s a n$ Agroekoteknologi, Fakultas Pertanian, Universitas Sultan Ageng Tirtayasa Jalan. Raya Jkt Km 4 \\ Pakupatan, Panancangan, Kec. Cipocok Jaya, Kota Serang, Banten 42124, \\ ${ }^{6} J u r u s a n$ Agribisnis, Fakultas Pertanian, Universitas Sultan Ageng Tirtayasa Jalan. Raya Jkt Km 4 \\ Pakupatan, Panancangan, Kec. Cipocok Jaya, Kota Serang, Banten \\ Diterima: 22 Oktober 2020/Disetujui: 27 November 2020 \\ *Korespondensi: fitria.eris@untirta.ac.id
}

Cara sitasi: Eris FR, Munandar A, Hidayat T, Kartina AM, Meutia, Anggraeni D. 2020. Karakteristik produk uli khas suku badui dengan penambahan daging ikan bandeng. Jurnal Pengolahan Hasil Perikanan Indonesia. 23(3): 479-485.

\begin{abstract}
Abstrak
Uli adalah pangan lokal khas suku Badui dengan bahan baku utama beras ketan. Produk tersebut memiliki kandungan karbohidrat yang tinggi, namun rendah jenis gizi lainnya. Oleh karena itu, peningkatan nilai gizi dilakukan melalui fortifikasi dengan penambahan daging ikan bandeng. Penelitian bertujuan menentukan perlakukan optimum dan karateristik kimia, fisik, serta hedonik produk uli khas Badui yang ditambahkan daging ikan bandeng. Penelitian ini dilakukan dalam beberapa tahap yaitu preparasi ikan bandeng, pembuatan uli, dan karakterisasi produk yang meliputi kimia (air, abu, protein, dan lemak), fisik (kekerasan), dan hedonik (rasa, warna, tekstur, dan aroma) dengan panelis tidak terlatih. Perlakuan yang diberikan adalah konsentrasi daging ikan bandeng dengan tiga taraf yaitu $0 \%, 10 \%, 20 \%$, dan 30\%. Kadar air produk uli tertinggi pada konsentrasi 30\% dengan nilai 49,44\%. Kadar abu berkisar antara 1,32-3,00\% dan optimum pada konsentrasi 20\%. Kadar protein tertinggi terdapat pada konsentrasi $20 \%$ dengan nilai 9,15\%, sedangkan kadar lemak paling tinggi pada konsentrasi $20 \%$ dengan nilai $8,82 \%$. Nilai kekerasan produk uli mengalami penurunan seiring dengan bertambahnya konsentrasi daging ikan bandeng dengan kisaran 2319,59-4184,85 gf. Hasil uji hedonik menunjukkan bahwa pada parameter rasa, warna, tekstur, dan aroma memiliki nilai yang tidak berpengaruh nyata, artinya penambahan daging ikan bandeng, uli masih disukai. Konsentrasi optimum penambahan daging ikan bandeng pada produk uli adalah $20 \%$.
\end{abstract}

Kata kunci: hedonik, pangan lokal, protein, uli

\section{Characteristics of Uli as a Typical Product of The Badui Tribe With The Addition of Milkfish Meat (Chanos chanos)}

\begin{abstract}
Uli is a local food of the Badui tribe made from sticky rice. Uli has a high carbohydrate content but is low in other types of nutrients. Therefore, to increase the nutritional value, milkfish meat can be added to the Uli. This study was aimed to determine effect of addition of milkfish meat on the chemical, physical, and organoleptic characteristics of the uli. This research included the preparation of milkfish, uli production and product characterization including chemical (moisture, ash, protein, and fat), physical (hardness), and organoleptic (taste, color, texture, and aroma). Three concentration of milkfish were added including $0 \%$, $10 \%, 20 \%$, and $30 \%$. The lowest moisture content of the uli was found at $30 \%$ concentration of milkfish with a $49.44 \%$ value. The ash content ranged from 1.32 to $3.00 \%$, and the lowest was at concentration of $20 \%$.
\end{abstract}


The highest protein content $(9.15 \%)$ was found at $20 \%$ concentration with value, while the highest levels of fat $(8.82 \%)$ were at concentration of $20 \%$. The hardness value of uli decreased with the increase in milkfish concentration with values ranging 2319.59-4184.85 gf. The organoleptic test results showed that the parameters of taste, color, texture, and aroma were not signif-icant affected, meaning that the addition of milkfish meat was still preferred. Thus, the optimum concentration of milkfish meat added in to the uli product was $20 \%$.

Keywords: local food, organoleptic, protein, uli

\section{PENDAHULUAN}

Suku Badui memiliki pola ketahanan pangan yang dipengaruhi sumberdaya alam dari hutan, baik dari hasil budidaya maupun langsung dari hutan. Eksplorasi pangan olahan lokal suku Badui sangat penting dilakukan sebagai warisan budaya. Suku Badui biasanya mengonsumsi nasi sebagai makanan pokok, ikan dan sayuran. Suku Badui memperoleh pangan memproduksi pangan sendiri di lahan pertaniannya atau pun membeli di pasar atau di warung yang ada di lingkungan mereka (Khomsan 1993). Produk pangan yang dihasilkan di antranya adalah wajik, uli, rengginang, tape ketan, gipang, getuk dangdeur, getuk cau panggalek, wedang jahe, sayur hiris, dodol.

Uli merupakan pangan olahan dengan bahan utama beras ketan melalui proses pengukusan dan penumbukan produk hingga lembut. Produk pangan ini bisa dikonsumsi langsung atau digoreng terlebih dahulu (Eris et al. 2017). Berdasarkan komposisi bahannya, produk uli mengandung karbohidrat yang tinggi, namun kandungan gizi lainnya sangat rendah sehingga untuk meningkatkan kandungan gizi perlu dilakukan fortifikasi dengan penambahan daging ikan bandeng (Chanos chanos).

Pada tahun 2018, tingkat konsumsi ikan di Provinsi Banten baru mencapai 33,53 kg dan masih di bawah angka nasional (DKP Banten 2018). Salah satu upaya untuk meningkatkan konsumsi ikan dilakukan melalui diversifikasi. Ikan bandeng merupakan komoditas perikanan utama Provinsi Banten yang dapat dimanfaatkan untuk diversifikasi. Berdasarkan BPS (2020), produksi ikan bandeng di Provinsi Banten mencapai 12.585 ton, terutama di wilayah Tangerang dan Serang yang mencapai $64 \%$ dan $28 \%$. Kebutuhan ikan bandeng untuk produksi sate bandeng adalah $300 \mathrm{~kg} / \mathrm{hari}$, selebihnya masih dijual dalam keadaan segar (DKP Banten 2019).

Penelitian yang terkait dengan diversifikasi dan pengolahan ikan bandeng adalah: bekasam dari ikan bandeng (Candra et al. 2007), ikan bandeng tanpa duri (Nusantari et al. 2016), pembuatan keripik kulit dan abon ikan bandeng oleh UKM (Sugito et al. 2019), dan pengolahan gipang dengan penambahan tepung tulang ikan bandeng (Jannah et al. 2020).

Fortifikasi produk uli dengan penambahan bahan baku pangan lokal belum banyak dilakukan. Peningkatan kandungan gizi produk uli dilakukan melalui penambahan daging ikan bandeng. Diversifikasi pada produk uli ini juga dilakukan sebagai upaya untuk meningkatkan konsumsi ikan, terutama di Provinsi Banten. Oleh karena itu, perlu dilakukan penelitian mengenai karakteristik produk uli khas Badui dengan penambahan daging ikan bandeng. Penelitian bertujuan menentukan perlakukan optimum dan karateristik kimia, fisik, serta hedonik produk uli khas Badui yang ditambahkan daging ikan bandeng.

\section{BAHAN DAN METODE Bahan dan Alat}

Bahan yang digunakan pada penelitian ini adalah ikan bandeng dengan ukuran 41/100 dari pasar Rau, Serang Banten, beras ketan, kelapa, garam, $\mathrm{CaO} 5 \%$, (Merck) tablet katalis (kjeltab), $\mathrm{H}_{2} \mathrm{SO}_{4}$ (Merck), $\mathrm{H}_{2} \mathrm{O}_{3}$ (Merck) $\mathrm{NaOH}$ (Merck), kloroform( Merck), $\mathrm{K}_{2} \mathrm{SO}_{4}($ Merck), alkohol 95\% dan akuades. Alat yang digunakan pada penelitian ini adalah tanur (SX3-2.5-10), oven (Etuve, Froilabo), texture analyzer (Brookfield CT3), score sheet, extractor soxhlet, dan mesin kjheltec. 


\section{Metode Penelitian}

Penelitian ini dilaksanakan dalam beberapa tahap yaitu preparasi ikan bandeng, pembuatan uli, dan karakterisasi produk yang meliputi kimia (uji proksimat), fisik (kekerasan), dan hedonik dengan panelis tidak terlatih.

\section{Prosedur Penelitian Pembuatan uli}

Tahapan proses pembuatan uli adalah perendaman beras ketan selama 24 jam, kemudian dicuci dan langsung dikukus hingga matang. Kelapa disiapkan dan dicampurkan garam secukupnya. Preparasi ikan bandeng, lalu fillet skinless. Ketan yang sudah dikukus dimasukkan ke dalam wadah yang berisi kelapa dan ditambahkan daging ikan bandeng sesuai konsentrasi $(0 \%, 10 \%, 20 \%$, dan $30 \%$, lalu diaduk hingga rata kemudian dikukus kembali. Setelah dikukus, kemudian dilakukan penumbukan hingga lembut (Figure 1).

\section{Prosedur pengujian}

Uji proksimat dilakukan berdasarkan BSN (2006) yang meliputi kadar air, abu, protein, dan lemak. Uji kekerasan dilakukan menggunakan texture analyzer (Brookfield CT3) dengan satuan gram force (gf) (Bourne 2002). Uji hedonik dilakukan berdasarkan Setyaningsih (2010) meliputi perubahan yang terjadi pada warna, aroma, tekstur, dan rasa. Uji ini dilakukan oleh 30 orang panelis tidak terlatih. Skala yang digunakan adalah angka 1 sampai dengan 5 , dimana $1=$ sangat tidak suka, 2 = tidak suka, 3 = biasa, $4=$ agak suka, $5=$ suka.

\section{Analisis data}

Karakterisasi produk uli dilakukan dengan metode eksperimental design dengan menggunakan rancangan acak lengkap (RAL). Perlakuan yang diberikan adalah konsentrasi daging ikan bandeng dengan empat taraf yaitu $0 \%, 10 \%$, 20\%, dan 30\%. Perlakuan dilakukan dengan tiga kali ulangan. Data yang diperoleh diolah dan diuji ANOVA untuk melihat perbedaan antar perlakuan. Hasil perhitungan yang menunjukkan pengaruh nyata maka dilakukan uji lanjut. Uji lanjut yang digunakan dalam penelitian ini adalah uji beda nyata terkecil (BNT).

\section{HASIL DAN PEMBAHASAN Karakteristik Kimia}

Karakteristik kimia produk uli khas Badui meliputi kadar air, abu, protein, dan lemak. Table 1 menunjukkan bahwa penambahan daging ikan bandeng berpengaruh nyata $(p<0,05)$ terhadap kadar air produk uli yang dihasilkan. Penambahan daging ikan hingga 30\% menyebabkan peningkatan kadar air, hal ini karena daging ikan mengandung air $\pm 80 \%$. Menurut Mufarihat et al. (2019), bahan baku yang digunakan dapat mengikat air dan dipengaruhi oleh proses pengolahan. Namun,
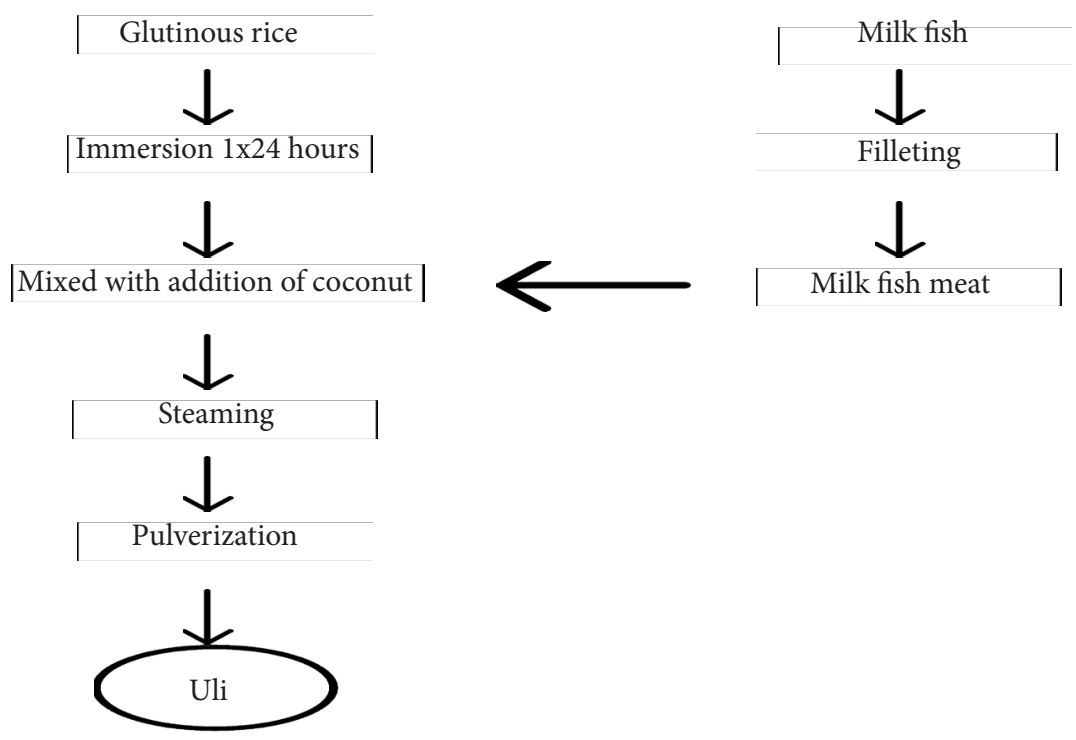

Figure 1 Uli Making Process 
Table 1 Chemical composition of uli product with enrichment of milkfish meat

\begin{tabular}{lcccc}
\hline \multicolumn{1}{c}{ Parameter } & \multicolumn{1}{c}{$0 \%$} & $10 \%$ & $20 \%$ & $30 \%$ \\
\hline Moisture & $44.26 \pm 0.17^{\mathrm{a}}$ & $45.81 \pm 0.15^{\mathrm{a}}$ & $47.72 \pm 0.02^{\mathrm{b}}$ & $49.44 \pm 0.09^{\mathrm{c}}$ \\
Ash & $1.37 \pm 0.03^{\mathrm{a}}$ & $0.99 \pm 0.02^{\mathrm{b}}$ & $1.01 \pm 0.00^{\mathrm{c}}$ & $1.92 \pm 0.02^{\mathrm{c}}$ \\
Protein & $4.21 \pm 0.00^{\mathrm{a}}$ & $4.82 \pm 0.13^{\mathrm{a}}$ & $9.15 \pm 0.13^{\mathrm{b}}$ & $8.76 \pm 0.14^{\mathrm{c}}$ \\
Fat & $12.34 \pm 0.23^{\mathrm{a}}$ & $14.91 \pm 0.01^{\mathrm{a}}$ & $8.82 \pm 0.08^{\mathrm{b}}$ & $8.69 \pm 0.02^{\mathrm{c}}$ \\
\hline
\end{tabular}

Note: different letters on the same line indicate significant differences $(p<0.05)$

kadar airnya masih di bawah 50\% sehingga masa simpannya relatif sama misalnya pada konsentrasi $0 \%$. Kadar air yang rendah pada produk menyebabkan daya awet menjadi lama walaupun tanpa pengawet (Handayani dan Kartikawati 2014).

Hasil analisis kadar abu menunjukkan penambahan daging ikan bandeng berpengaruh nyata $(p<0,05)$. Peningkatan kadar abu produk uli terjadi karena adanya penambahan daging ikan bandeng. Menurut Hafiluddin et al. (2014), kadar abu ikan bandeng berkisar antara 1,32-3,00\% yang mengandung mineral mikro dan makro yang dibutuhkan oleh tubuh. Berdasarkan nilai kadar abunya, penambahan daging ikan bandeng optimum terdapat pada konsentrasi $30 \%$ dengan nilai $1,92 \%$.

Analisis kadar protein, Table 1 menunjukkan hasil yang berpengaruh nyata $(p<0,05)$ dan berbeda nyata antara konsentrasi $0-10 \%$ dengan 20-30\%. Penambahan 10\% daging ikan bandeng masih rendah sehingga tidak berbeda dengan 0\%, sedangkan pada konsentrasi $20 \%$ peningkatan protein produk uli mencapai hingga 9,15\% dan turun secara proporsionl pada konsentrasi 30\%. Kenaikan jumlah protein pada uli tentnya dipengaruhi penambahan daging ikan bandeng. Kandungan protein pada ikan bandeng berkisar antara 14,84-23,53\% (Hafiluddin et al. 2014), protein tersebut tersusun dari jenis asam amino baik esensial maupun non esensial. Hasil analisis menunjukkan bahwa penambahan daging bandeng optimum terdapat konsentrasi 20\% dengan nilai mencapai 9,15\%.

Kadar lemak produk uli terjadi penurunan yang berpengaruh nyata $(p<0,05)$. Penurunan kandungan lemak dari konsentrasi 10\%-30\% disebabkan karena penambahan daging ikan bandeng tidak memberikan pengaruh. Kandungan lemak ikan bandeng hanya $1,54 \%$ sehingga terjadi penurunan secara proporsional. kandungan lemaknya juga merupakan asam lemak tidak jenuh yang mudah teroksidasi. Berdasarkan analisis tersebut, kadar lemak optimum pada produk uli terdapat pada konsentrasi $20 \%$ dengan nilai $8,82 \%$.

\section{Karakteristik Fisik}

Karakteristik fisik produk uli khas Badui diukur menggunakan parameter uji kekerasan. Figure 2, hasil uji kekerasan menunjukkan bahwa penambahan daging ikan bandeng berpengaruh nyata $(p<0,05)$ terhadap kekerasan produk uli. Analisis BNT menunjukkan bahwa antar perlakuan berbeda nyata. Peningkatan konsentrasi penambahan daging ikan bandeng menghasilkan nilai kekerasan produk uli yang semakin menurun. Penurunan nilai kekerasan produk uli berkaitan dengan kandungan patinya.

Amilosa pada pati yang terdapat pada beras ketan memainkan peran yang penting dalam memengaruhi tekstur, utamanya nilai kekerasan. Jika kandungan amilosanya tinggi maka produk yang dihasilkan memiliki kekerasan yang tinggi (Mayyawadee dan Gerhard 2010). Beras ketan hampir tidak memiliki amilosa (0-2\%), ditambahkan adanya peningkatan daging ikan menyebabkan jumlahnya menurun sehingga nilai kekerasan produk uli semakin menurun. Nilai kekerasan yang paling optimum terdapat pada konsentrasi $20 \%$ dengan nilai 3105,43 gf.

\section{Karakteristik Hedonik}

Hasil analisis statistik menunjukkan bahwa penambahan daging ikan bandeng tidak berpengaruh nyata $(p>0,05)$ terhadap rasa, warna, tekstur, dan aroma produk uli. Hal ini menunjukkan bahwa penambahan daging ikan bandeng dapat diterima oleh panelis. 


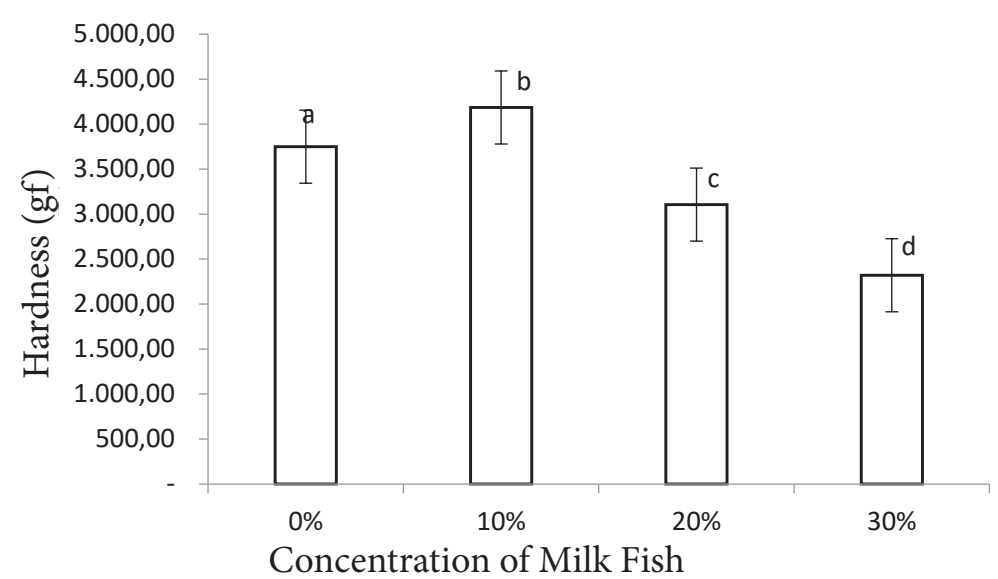

Figure 2 Hardness Value of Uli Product with Enrichment of Milkfish Meat

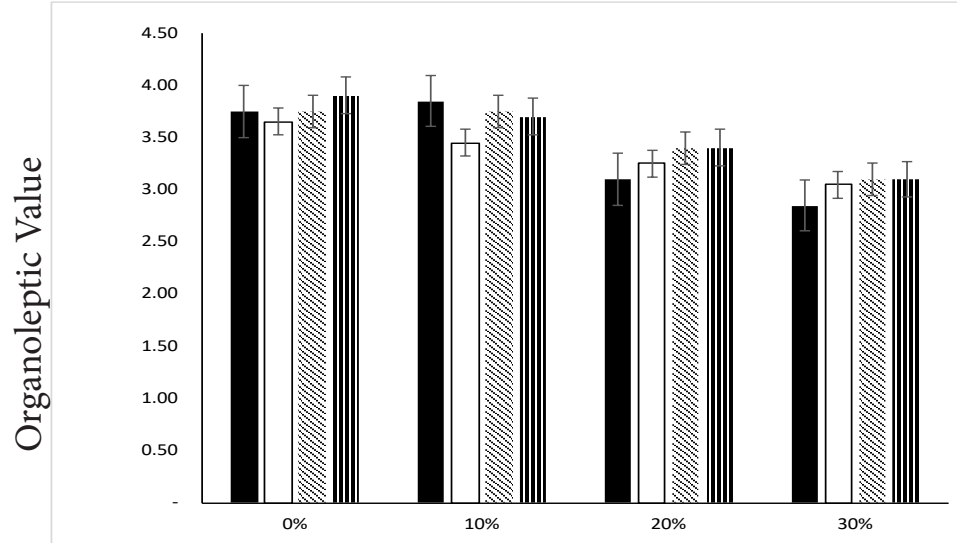

Concentration of Milk Fish

Figure 3 Hedonic Test Results of Uli Product with Enrichment of Milkfish Meat;

taste; $\square$ color; $\mathbb{Q}$ texture; IIII odor.

Hasil uji hedonik pada rasa produk berkisar pada 2,85-3,75. Rasa uli yang ditambahkan daging ikan dipengaruhi oleh kandungan protein. Hal ini dikarenakan adanya asam glutamat pada daging ikan yang memiliki rasa gurih, sensasi rasa tersebut terjadi karena adanya proses pengukusan yang menyebabkan protein terdenaturasi (Judith et al. 2016).

Penambahan daging ikan bandeng menghasilkan aroma yang tidak berbeda pada produk uli pada konsentrasi $0 \%$ dengan nilai pada kisaran 3,10-3,90. Hal ini dikarenakan bahan baku yang digunakan masih sangat segar. Selain faktor kesegaran, bau lumpur pada ikan bandeng juga harus diperhatikan karena adanya kandungan geosmin (Hafiluddin et al. 2014). Warna yang dihasilkan produk uli yang ditambahkan daging ikan bandeng juga tidak memiliki perbedaan dengan konsentrasi $0 \%$. Hal ini ditunjukkan dari nilai organolpetiknya yang berkisar pada 3,05-3,65. Hasil tersebut menunjukkan bahwa pemilihan bahan baku sangat penting, ikan bandeng memiliki daging yang berwarna putih sehingga tidak berpengaruh pada warna produk uli.

Parameter tekstur, penambahan daging ikan bandeng pada produk uli khas Badui masih disukai oleh panelis dengan kisaran nilai 3,103,75 . Tekstur uli yang disukai oleh masyarakat tidak terlalu keras, tapi juga tidak terlalu lunak. Pada saat digoreng, permukaan uli memiliki kerenyahan dan bagian dalam masih lunak. Tekstur uli yang dihasilkan dengan penambahan daging ikan bandeng masih memiliki karakteristik tersebut sehingga masih disukai oleh panelis. 


\section{KESIMPULAN}

Berdasarkan hasil pengujian fisik, kimia dan hedonik, maka didapatkan konsentrasi optimum yaitu $20 \%$. Pada konsentrasi tersebut memiliki nilai protein yang tinggi sehingga penambahan daging ikan bandeng dapat menambah kandungan gizi pada produk uli. Produk uli dengan penambahan daging ikan bandeng masih dalam tingkat agak suka, sehingga perlu dilakukan penambahan flavor untuk fortifikasi tahap selanjutnya agar rasa yang dihasilkan dapat diterima konsumen.

\section{UCAPAN TERIMA KASIH}

Ucapan terima kasih disampaikan pada Islamic Development Bank (IsDB) pada Hibah Research Grant UNTIRTA 2019 yang telah mendanai penelitian ini.

\section{DAFTAR PUSTAKA}

Badan Pusat Statistik Provinsi Banten [BPS Provinsi Banten]. 2020. Provinsi Banten dalam Angka. Serang (ID): BPS Provinsi Banten.

Bourne MC. 2002. Food, Texture and Viscosity Concept and Measurement. London (GB): Academic Press.

Badan Standardisasi Nasional [BSN]. 2006. Cara Uji Kimia SNI 01-2354. Jakarta (ID): Badan Standardisasi Nasional Indonesia.

Candra JI, Zahiruddin W, Desniar. 2007. Isolasi dan karakterisasi bakteri asam laktat dari produk bekasam ikan bandeng (Chanos chanos). Buletin Teknologi Hasil Perikanan. 10(2):14-24

Dinas Kelautan dan Perikanan Provinsi Banten [DKP Provinsi Banten]. 2018. Kelautan dan Perikanan dalam Angka. Serang (ID): Dinas Dinas Kelautan dan Perikanan Provinsi Banten.

Dinas Kelautan dan Perikanan Provinsi Banten [DKP Provinsi Banten]. 2019. Profil Potensi Usaha dan Investasi Komoditas Bandeng di Kabupaten Serang. Jakarta (ID): Kementerian Kelautan dan Perikanan.

Eris FR, Kartina AM, Anggraeni D, dan Mirajiani. 2017. Identifikasi dan Karakterisasi Bahan Pangan Etnis Badui Berbasis Kearifan Lokal dalam Rangka Mendukung Ketahanan Pangan.
[Laporan]. Serang (ID): Universitas Sultan Ageng Tirtayasa.

Handayani DI dan Kartikawati D. 2015. Stik lele alternatif diversifikasi olahan lele (clarias sp) tanpa limbah berkalsium tinggi. Serat Acitya. 4(1): 109-117.

Hafiluddin, Perwitasari D, dan Budiarto S. 2014. Analisis kandungan gizi dan bau lumpur ikan bandeng (chanos chanos) dari dua lokasi yang berbeda. Jurnal Kelautan. 7(1): 33-44.

Jannah BN, Eris FR, Kuswardhani $\mathrm{N}$ dan Munandar A. 2020. Characteristics of gipang, a raditional food of badui tribe, added with milkfish bone flour to improve calcium and phosphor content. Jurnal Ilmiah Perikanan dan Kelautan. 12(2): 276-285

Judith F, Buchari D, dan Sumarto. 2016. Pengaruh penambahan daging ikan patin (pangasius hypopthalmus) pada pengolahan rengginang ubi kayu (manihot esculenta c) terhadap penilaian hedonik. Jurnal Online Mahasiswa Unri. 3(1): 1-10.

Khomsan A. 1993. Keragaan kebiasaan makan: proyek diversifikasi pangan dan gizi. Media Gizi dan Keluarga. 17(2): 2933.

Mayyawadee S dan Gerhard S. 2010. Effect of blending cassava starch, rice, waxy rice and wheat flour on physicochemical properties of flour mixtures and mechanical and sound emission properties of cassava crackers. Journal of Food Engineering 100: 12-24.

Mufarihat IK, Haryati S, dan Munandar A. 2019. Karakteristik Bontot dengan Kombinasi Daging Ikan Payus (Elops hawaiiensis) dan Ikan Bulan Bulan (Megalops cyprinoides). Jurnal Pengolahan Hasil Perikanan Indonesia. 22(3): 476482.

Nurhayati, Salamah E, Tampubolon K, Apriland A. 2011. Peranan inhibitor katepsin dari ikan patin (Pangasius hypophthalmus) untuk menghambat kemunduran mutu ikan bandeng (Chanos chanos Forskal). Jurnal Pengolahan Hasil Perikanan Indonesia. 14(1): 49-55

Nusantari E, Abdul A, Harmain RM. 2016. 
Ikan bandeng tanpa duri (Chanos chanos) sebagai peluang bisnis masyarakat desa Mootinelo, Kabupaten Gorontalo Utara, Provinsi Gorontalo. Agrokreatif Jurnal Ilmiah Pengabdian kepada Masyarakat. 3(1): 78-87.

Setyaningsih D, Apriyantono A dan Sari MP. 2010. Analisis Sensori untuk Industri
Pangan dan Agro. Bogor (ID): IPB Press. Sugito, Prahutama A, Tarno , Hoyyi A. 2019. Diversifikasi olahan ikan bandeng oleh ukm primadona dalam program pengabdian ibpe 2016-2018. E-DIMAS: Jurnal Pengabdian kepada Masyarakat. 10(1): 100-104 